\title{
Optimasi dan Karakterisasi Pengeringan Ekstrak Buah Mengkudu dengan Penambahan Bahan Pengering Synthetic Amorphous Silica
}

\author{
Nina Dewi Oktaviyanti ${ }^{1}$, Christina Avanti² dan Fajar Tri Yulianto' ${ }^{1}$ \\ 1 Departemen Biologi Farmasi, Fakultas Farmasi Universitas Surabaya, Surabaya \\ 2 Departemen Farmasetika, Fakultas Farmasi Universitas Surabaya, Surabaya
}

Korespondensi: Nina Dewi Oktaviyanti

Email: nina_dewi@staff.ubaya.ac.id

\begin{abstract}
ABSTRAK: Mengkudu (Morinda citrifolia L.) telah lama digunakan di Indonesia dan seluruh dunia sebagai obat tradisional dan suplemen. Proses ekstraksi dari buah mengkudu menghasilkan ekstrak kental yang kurang dapat diterima oleh masyarakat karena bau dan konsistensinya. Oleh karena itu, perlu adanya alternatif proses pengeringan dari ekstrak kental menjadi ekstrak kering yang tetap dapat menjaga kualitas, efektifitas, dan keamanan dari produk akhirnya. Penelitian ini bertujuan untuk mengkarakterisasi dan menentukan penambahan Synthetic Amorphous Silica (SAS) yang paling efektif sebagai bahan pengering pada proses pengeringan ekstrak buah mengkudu. Parameter yang dianalisis meliputi karakteristik fisik dan kimia. Penambahan SAS terhadap ekstrak dengan perbandingan 1:2 menunjukkan hasil yang paling efektif terhadap kandungan lembab yaitu 3,20 \% 0,07 . Hasil tersebut selanjutnya dilakukan konfirmasi dengan parameter uji lainnya yaitu sifat alir, distribusi ukuran partikel, bobot jenis, profil KLT dan ternyata seluruh hasil dari parameter tersebut sesuai dengan ketentuan. Ekstrak kering hasil pengeringan dengan SAS perbandingan 1:2 memberikan kecepatan alir sebesar 11,11 \pm 0,2092 g/detik, jumlah fines sebanyak 10,20\%, dan kompresibilitas sebesar $12,18 \% \pm 0,02$.
\end{abstract}

Kata kunci: Morinda citrifolia, pengeringan, ekstrak, silica

\begin{abstract}
Noni (Morinda citrifolia L.) has been used for a long time in Indonesia and worldwide for traditional medicine and supplement. The extraction process of noni fruit produces thick extract which less acceptable because its smell and consistency. Therefore, there should be an alternative drying process of extract into dry extract that can maintain quality, efficacy and safety of the final product. Aim of this study was to characterize and determine the most effective ratio of Synthetic Amorphous Silica (SAS) addition as drying agent in the drying process of noni fruit extract. Parameters were analyzed include physical characteristic and chemical characteristic. Addition of SAS to the extract with the ratio 1:2 showed the most effective results on moisture content of dry extract, i.e. $3.20 \% \pm 0.07$. These results were confirmed with other parameter tests such as free flowing, particle distribution, density, TLC profile and the results also met the requirements. Dry extract yield from addition of the SAS with the ratio $1: 2$ showed $11.11 \pm 0.21 \mathrm{~g} / \mathrm{s}$ flow rate; $10.20 \%$ amount of fines; and compressibility about $12.18 \% \pm$ 0.02 .
\end{abstract}

Keywords: Morinda citrifolia, drying, extract, silica 


\section{Pendahuluan}

Morinda citrifolia L. merupakan tanaman yang termasuk dalam familia Rubiaceae, secara luas dikenal sebagai noni dan di Indonesia sebagai mengkudu. Secara empiris, hampir seluruh bagian tanaman mengkudu telah dimanfaatkan oleh masyarakat sebagai obat maupun suplemen penunjang kesehatan, salah satunya adalah buahnya yang sering dibuat dalam bentuk jus. Telah dilaporkan juga aktivitas dari buah mengkudu pada beberapa penyakit [1]. Manfaatnya yang begitu banyak membuat mengkudu potensial untuk dikembangkan menjadi sediaan obat herbal terstandar bahkan fitofarmaka. Masalah yang muncul adalah buah mengkudu dalam bentuk ekstrak kental kurang bisa diterima secara organoleptis baik dari segi bau, bentuk, warna, dan rasa oleh masyarakat untuk dikonsumsi [2]. Bau yang tidak sedap tersebut berasal dari sejumlah zat asam yang terkandung dalam buah mengkudu yang justru memiliki khasiat untuk kesehatan [3]. Salah satu alternatif yang dapat dilakukan adalah melakukan formulasi ekstrak buah mengkudu menjadi bentuk sediaan padat seperti kapsul atau tablet guna meningkatkan acceptability hingga ke tangan pasien. Pada proses pembuatan sediaan padat tersebut perlu dilakukan proses pengeringan ekstrak kental menjadi ekstrak kering.

Pengeringan merupakan proses untuk mengeliminasi keadaan lembab yang dapat merusak kestabilan sediaan dan potensi pertumbuhan mikroba. Terdapat banyak metode pengeringan yang dapat digunakan. Penelitian terdahulu menunjukkan bahwa terjadi penurunan yang signifikan pada aktivitas antioksidan dan kandungan total fenol buah mengkudu akibat pemanasan pada suhu tinggi $140^{\circ} \mathrm{C}$ secara spray drying [4]. Oleh karena itu, perlu digunakan alternatif lain proses pengeringan ekstrak kental buah mengkudu menjadi ekstrak kering tanpa menggunakan suhu tinggi, salah satu upaya yang dapat dilakukan untuk menghindari rusaknya komponen bioaktif selama proses pengeringan ekstrak mengkudu adalah pengeringan dengan menggunakan bahan tambahan yang dapat berfungsi sebagai pengering. Pengeringan dengan menggunakan bahan pengering dapat menghindari penggunaan panas yang terlalu tinggi sehingga stabilitas komponen bioaktif lebih terjaga dan yang terpenting adalah hemat dalam penggunaan energi.

Bahan pengering yang sering digunakan adalah synthetic amorphous silica (SAS). Synthetic amorphous silica banyak digunakan pada berbagai produk kosmetik, farmasi, dan makanan. SAS berperan sebagai agent yang dapat memperbaiki sifat alir pada sediaan. SAS merupakan bahan penyerap yang baik karena porositasnya tinggi sehingga SAS digunakan sebagai adsorbing agent [5].

Ekstrak atau sediaan galenik lainnya perlu ditetapkan standar mutu dan keamanan untuk menjaga kualitas. Begitu pula pada ekstrak kental harus memenuhi syarat standarisasi ekstrak yaitu Quality, Efficacy, dan Safety. Walaupun melalui proses pengeringan, ekstrak tetap harus terjaga ketiga aspek tersebut [6].

Penelitian ini bertujuan untuk menentukan perbandingan efektif dari penambahan SAS terhadap ekstrak kental buah mengkudu berdasarkan parameter fisika dan kimianya. Parameter fisik yang diuji meliputi kandungan lembab, sifat alir, distribusi ukuran partikel, dan bobot jenis. Sementara parameter kimia diuji dengan melihat profil KLT-nya.

\section{Bahan dan Metode}

\subsection{Bahan penelitian}

Bahan tanaman yang digunakan pada penelitian ini adalah buah mengkudu (Morinda citrifolia L.) segar yang tepat masak berwarna kuningputih dan tidak lunak yang diperoleh dari Materia Medika, Batu pada bulan September 2016. Bahan kimia yang digunakan pada penelitian ini adalah Synthetic Amorphous Silica (Cabot Corp), etanol 96\% p.a. (Mallinckrodt), toluen p.a. (Riedel-de Haen), eter p.a. (Riedel-de Haen), asam asetat (Riedel-de Haen), KOH (Merck) dan lempeng KLT Silica Gel GF 254. 


\subsection{Instrumen penelitian}

Instrumen yang digunakan dalam penelitian ini adalah neraca gram (NHK), neraca analitik (Ohauss $\AA /$ Sartorius $\AA$ Analytical balance tipe BP190S), 1 set Rotary evaporator (Buchi ${ }^{\circledR}$ ), eksikator (Glaswerk werthem), oven (Binder $®)$, kertas saring (Whatmann $\left.{ }^{\circledR}\right)$, water bath (Memert W 400®), moisture content balance (Sartorius), corong standar, stopwatch (Casioß), cawan porselen, botol timbang (Pyrex®), bejana eluasi (CAMAG®), pipa kapiler, dan berbagai alat gelas laboratorium.

\subsection{Pembuatan ekstrak kering buah mengkudu}

Buah mengkudu dikumpulkan, dicuci bersih dengan air mengalir hingga bebas dari kotorankotoran yang melekat, dilakukan sortasi basah, dikecilkan ukurannya dengan pengirisan melintang dengan tebal $\pm 0,5 \mathrm{~cm}$, dikeringkan menggunakan bantuan sinar matahari dengan ditutup kain hitam. Setelah kering, kemudian diserbuk dan diayak menggunakan ayakan mesh 40 .

Sebanyak 500 gram serbuk simplisia buah mengkudu diekstraksi dengan metode maserasi selama 24 jam dengan pelarut etanol 96\% sebanyak 4 liter. Filtrat dikumpulkan dengan proses penyaringan dengan menggunakan corong Buchner, sedangkan pada ampas dilakukan re-maserasi sebanyak 4 kali. Seluruh filtrat hasil maserasi dikumpulkan dan dipekatkan menggunakan rotary evaporator pada suhu $60^{\circ} \mathrm{C}$.

Ekstrak kental yang diperoleh selanjutnya dibuat menjadi ekstrak kering melalui penambahan bahan pengering Synthetic Amorphous Silica (SAS) dengan beberapa perbandingan (ekstrak kental dan bahan pengering) yaitu 2:1, 1:1, 1:2, dan 1:3.

\subsection{Kandungan lembab (moisture content)}

Moisture content atau kandungan lembab dari ekstrak kering diperiksa dengan menggunakan moisture analyzer [7]. Pemeriksaan moisture content ekstrak dilakukan dengan cara menimbang sebanyak 5 g ekstrak kering yang sudah diratakan permukannya diletakkan pada wadah sampel pada moisture content balance. Letak lampu pe- manas diatur tepat di atas bahan. Selama proses pengeringan berlangsung, setiap 15 menit akan ditunjukkan bobot bahan. Proses pengeringan dikatakan sempurna apabila setelah interval $3 \mathrm{x}$ 15 menit tidak menunjukkan adanya perubahan pada bobot bahan. Bobot serbuk akhir kemudian dicatat dan dihitung persentase moisture content pada ekstrak kering mengkudu dengan rumus sebagai berikut:

$$
\% M C=\frac{W-W o}{W o} \times 100 \%
$$

Keterangan :

$\mathrm{W}=$ Bobot serbuk awal (g)

Wo = Bobot serbuk akhir $(\mathrm{g})$

$\% \mathrm{MC}=$ Persentase kandungan lembab

\subsection{Sifat alir}

Pengukuran sifat alir serbuk ekstrak kering dilakukan dengan mengalirkan serbuk pada sebuah corong gelas. Suatu penutup sederhana ditempatkan pada lubang keluar corong yang sebelumnya telah diisi dengan ekstrak kering sebanyak $100 \mathrm{~g}$. Dilakukan pencatatan terhadap waktu yang dibutuhkan serbuk untuk keluar dari corong setelah penutup dibuka. Kecepatan alir dihitung dengan membagi massa serbuk dengan waktu yang dibutuhkan serbuk untuk keluar dari corong. Sementara sudut istirahat diukur dari perbandingan tinggi dengan jari-jari kerucut serbuk yang keluar dari corong [7].

\subsection{Distribusi ukuran partikel}

Uji distribusi ukuran partikel dilakukan dengan melewatkan serbuk pada ayakan dengan ukuran-ukuran tertentu yang disusun berurutan dari ukuran lubang besar ke kecil dan diberi getaran mekanis. Partikel yang terdistribusi pada ayakan selanjutnya dihitung dengan cara menimbang ayakan beserta serbuk di dalamnya dikurangi dengan bobot ayakan kosong [8, 9].

\subsection{Bobot jenis (density) dan indeks kompresibi- litas}

Bobot jenis yang diukur adalah bobot jenis nyata (bulk density) dan bobot jenis mampat (tap 
density). Bobot jenis nyata dihitung dengan membagi bobot serbuk (g) dengan volume serbuk $\left(\mathrm{cm}^{3}\right)$ yang diukur dengan menggunakan gelas ukur. Bobot jenis mampat dihitung dengan menggunakan cara yang sama, namun serbuk dalam gelas ukur dimampatkan terlebih dahulu dengan pengetukan sebanyak 500 kali $[7,10]$. Kedua bobot jenis tersebut selanjutnya digunakan untuk menghitung persen kompresibilitas.

$$
\% \text { Kompresibilitas }=\frac{\text { Bobot jenis nyata }}{\text { Bobot jenis mampat }} \times 100 \%
$$

\subsection{Profil senyawa kimia dengan metode KLT}

Ekstrak kental buah mengkudu dilarutkan dengan metanol dan ditotolkan pada lempeng silika gel GF 254 ukuran 2,5 x 10 cm menggunakan pipa kapiler. Lempeng KLT kemudian dieluasi dengan fase gerak eter P-benzen P-asam asetat (5:5:1). Noda diamati pada sinar UV-365 nm [11]. Prosedur yang sama juga dilakukan terhadap serbuk kering buah mengkudu hasil pengeringan. Suatu simplisia dikatakan mengandung senyawa golongan kumarin (scopoletin) apabila memberikan noda biru pada sinar UV-365 [12].

\section{Hasil dan Diskusi}

Pada pembuatan tablet, kelembaban serbuk yang terlalu tinggi dapat mempengaruhi kualitas produk akhir dan dapat mengganggu aliran serbuk ke dalam lubang cetakan. Secara teknis, kelembaban serbuk menyebabkan serbuk lekat pada cetakan dan punch (picking). Sebaliknya, apabila kelembaban relatif rendah friabilitas makin tinggi dan tablet akan mudah pecah. Selain itu pada pembuatan kapsul atau tablet, adanya kandungan lembab yang tinggi dapat berpotensi meningkatnya pertumbuhan jamur dan mikroba $[13,14]$.

Hasil penetapan persen moisture content dari ekstrak kering ditunjukkan pada Tabel 1 . Semakin tinggi perbandingan jumlah pengering yang ditambahkan terhadap ekstrak kental, maka semakin rendah kandungan lembab. Kadar lembab yang baik berada antara 2-4\% [15]. Diantara seluruh perbandingan yang ada, perbandingan 1:2 dan 1:3 masuk dalam rentang. Pada formulasi sediaan farmasi, eksipien yang digunakan harus efektif begitu pula pada proses pengeringan. Komposisi pengering yang dipilih harus memberikan hasil yang optimal dengan jumlah pengering yang minimal. Perbandingan 1:3 memberikan nilai kandungan lembab yang lebih rendah daripada perbandingan 1:2 namun dinyatakan tidak signifikan secara statistik (Sig=0,570). Dengan demikian, berdasarkan parameter kandungan lembab, ekstrak kering dengan perbandingan 1:2 lebih dipilih daripada 1:3. Namun, hal ini perlu dirujuk dengan menggunakan parameter fisik yang lain seperti sifat alir, distribusi ukuran partikel, dan kompresibilitas.

Sifat alir serbuk sangat penting untuk memastikan efisiensi pencampuran dan keseragaman bobot. Bahan yang mempunyai sifat alir yang kurang baik dapat menyebabkan ketidakseragaman ukuran dan bentuk dari tablet yang dihasilkan atau pada saat pengisian pada cangkang kap-

Tabel 1. Parameter fisika ekstrak kering buah mengkudu hasil pengeringan SAS pada berbagai perbandingan

\begin{tabular}{lllll}
\hline \multirow{2}{*}{ Parameter fisika } & \multicolumn{4}{l}{ Perbandingan ekstrak dan pengering } \\
\cline { 2 - 5 } & $\mathbf{2 : 1}$ & $\mathbf{1 : 1}$ & $\mathbf{1 : 2}$ & $\mathbf{1 : 3}$ \\
\hline Kandungan lembab (\%) & $6,12 \pm 0,27$ & $5,34 \pm 0,57$ & $3,20 \pm 0,07$ & $3,08 \pm 0,11$ \\
Kecepatan alir (g/detik) & $6,09 \pm 0,31$ & $10,16 \pm 0,16$ & $11,11 \pm 0,21$ & $12,23 \pm 0,22$ \\
Sudut istirahat & $32,28 \pm 0,61$ & $32,29 \pm 0,60$ & $33,12 \pm 0,52$ & $31,34 \pm 0,60$ \\
Persentase fines (\%) & 0 & 11,11 & 10,20 & 14,14 \\
\hline Kompresibilitas (\%) & $21,04 \pm 0,01$ & $6,54 \pm 0,01$ & $12,18 \pm 0,02$ & $20,66 \pm 0,02$ \\
\hline
\end{tabular}


sul. Sifat alir yang baik ditunjukkan apabila waktu mengalir dari $100 \mathrm{~g}$ serbuk adalah $\leq 10$ detik atau dengan kata lain kecepatan mengalirnya $\geq$ 10 g/detik [7]. Pada Tabel 1 menunjukkan bahwa ekstrak kering hasil pengeringan dengan perbandingan 1:1, 1:2, dan 1:3 memberikan kecepatan alir yang baik.

Parameter fisik yang menggambarkan gambaran ukuran partikel yang menyusun serbuk adalah distribusi ukuran partikel. Distribusi ukuran yang baik adalah yang sesuai dengan kurva distribusi normal, dimana terdapat sejumlah kecil fines. Namun demikian, keberadaan fines dibutuhkan karena berfungsi untuk mengisi ruang diantara partikel-partikel besar sehingga pada saat dikempa menjadi mampat. Persen fines yang dikehendaki adalah 10-20\% $[9,16]$. Perbedaan ukuran partikel serbuk yang besar dapat mempengaruhi proses pengisian ruang antar partikel dan aliran ke dalam ruang kompresi sehingga mempengaruhi keseragaman bobot dari sediaan. Selain itu, ukuran partikel juga dapat mempengaruhi stabilitas serbuk. Ukuran partikel yang terlalu kecil menyebabkan lebih mudah terpapar oleh kelembaban di udara. Proporsi partikel halus (fines) digunakan untuk menggambarkan sifat alir suatu serbuk [7].

Persentase fines dari seluruh ekstrak kering hasil penambahan bahan pengering berbagai perbandingan dirangkum pada Tabel 1 dan profil distribusi ukuran partikel disajikan pada Gambar 1. Seluruh perbandingan pengering memberikan persentase fines yang sesuai ketentuan, kecuali perbandingan 2:1.

Kompresibilitas adalah kemampuan serbuk untuk menyusun diri pada ruang cetak kemudian mengalami deformasi menjadi bentuk yang mampat dan menjadi massa yang kompak jika serbuk

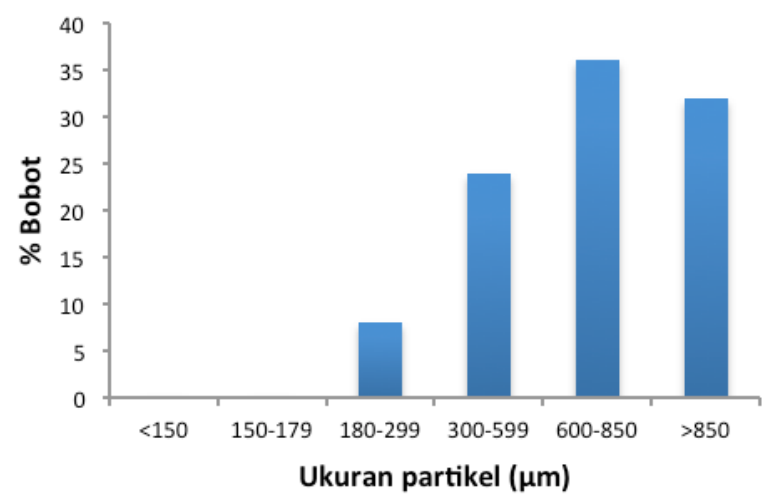

(A)

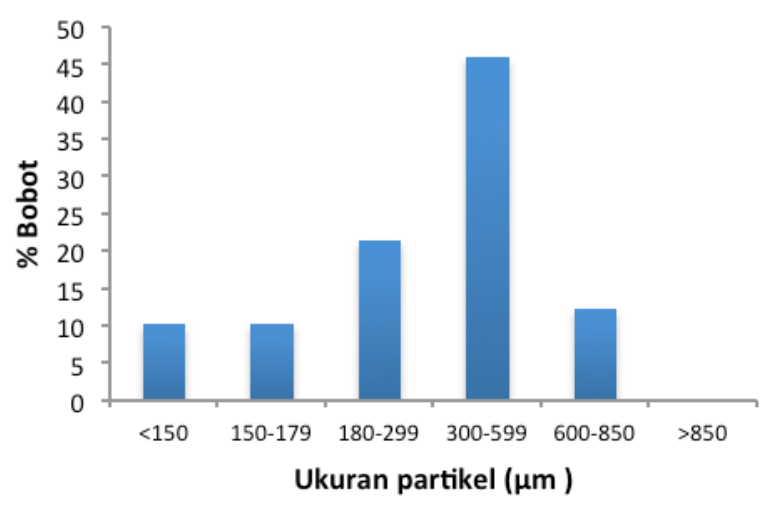

(C)

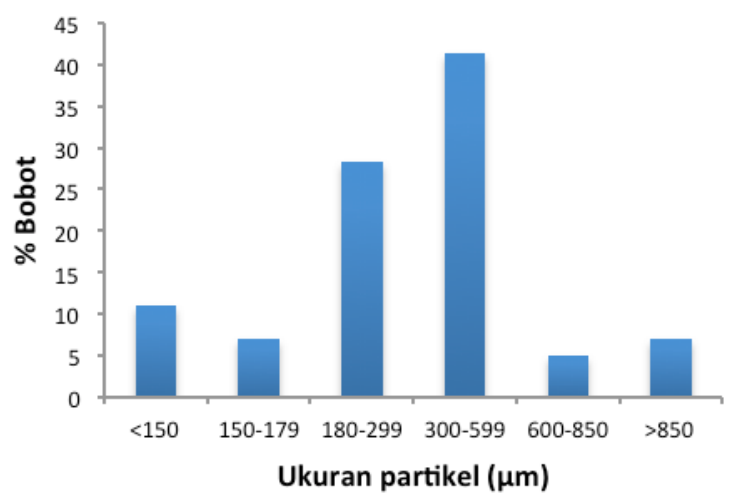

(B)

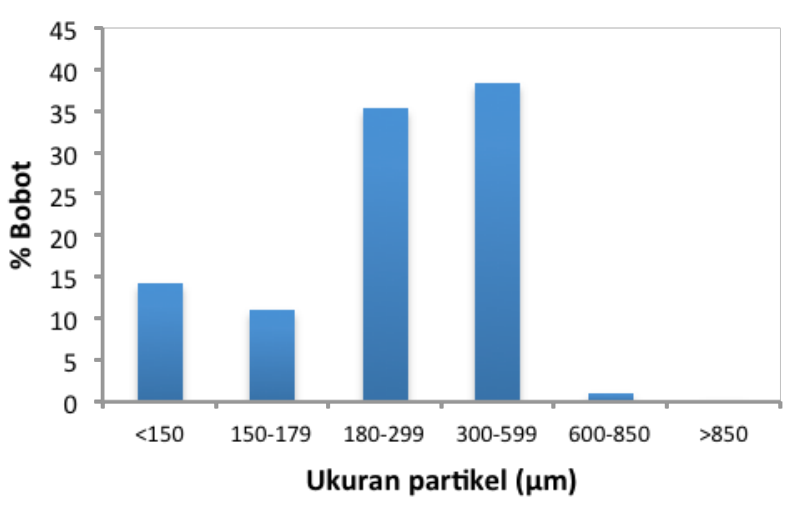

(D)

Gambar 1. Profil distribusi ukuran partikel ekstrak kering buah mengkudu hasil pengeringan dengan perbandingan ekstrak dan pengering SAS sebesar (A) 2:1; (B) 1:1; (C) 1:2; (D) 1:3 
dikompresi. Kompresibilitas yang baik dapat berperan dalam menghasilkan sifat alir yang baik. Rentang kompresibilitas yang baik adalah pada rentang $5-25 \%[7,17]$. Dalam bentuk sediaan jadi seperti tablet, kompresibilitas sangat penting karena mempengaruhi pada saat pencetakan. Jika kompresibilitas rendah maka tablet yang dihasilkan memiliki kekerasan yang rendah, akibatnya tablet akan rapuh dan mudah hancur. Sebaliknya, jika kompresibilitas tinggi maka tablet akan terlalu keras, akibatnya tablet akan susah pecah sehingga memerlukan waktu lebih lama untuk melepaskan bahan aktif. Indeks kompresibilitas dihitung dari data hasil pengukuran berat jenis nyata dan berat jenis mampat yang kemudian disajikan pada Tabel 1. Hasil menunjukkan bahwa indeks kompresibilitas semua perbandingan masuk pada rentang indeks kompresibilitas walaupun polanya berbeda.

Selain parameter fisika, penentuan komposisi pengering dilakukan konfirmasi juga melalui pengujian parameter kimia dengan menggunakan metode KLT. Scopoletin merupakan senyawa golongan kumarin yang menjadi major compound dan digunakan sebagai marker untuk tanaman ini [18], sehingga sistem KLT yang digunakan bertujuan untuk menampilkan profil senyawa tersebut. Hasil pengujian KLT sebelum dan sesudah pengeringan seluruh perbandingan yang divisualisasi pada UV 365 ditunjukkan pada Gambar 2.
Profil KLT menunjukkan adanya noda berfluoresensi biru pada sinar UV-365nm yang diduga kuat adalah senyawa golongan kumarin yakni scopoletin [12]. Noda tersebut memiliki Rf yang sama yakni 0,44 pada masing-masing lempeng. Proses pengeringan dengan menggunakan SAS dengan berbagai perbandingan tidak menunjukkan adanya perubahan terhadap senyawa yang diduga sebagai scopoletin tersebut.

\section{Kesimpulan}

Berdasarkan parameter kandungan lembab, perbandingan pengering SAS pada proses pengeringan buah mengkudu yang paling efektif yaitu 1:2 (ekstrak kental dan pengering). Ekstrak kering hasil pengeringan dengan perbandingan tersebut juga memberikan hasil yang baik pada parameter fisik yang lain yaitu sifat alir, distribusi ukuran partikel, dan indeks kompresibilitas. Pengeringan juga tidak menunjukkan adanya perubahan profil senyawa kimia yang diduga marker dari buah mengkudu.

\section{Ucapan terima kasih}

Peneliti mengucapkan terimakasih kepada Universitas Surabaya atas pendanaan penelitian

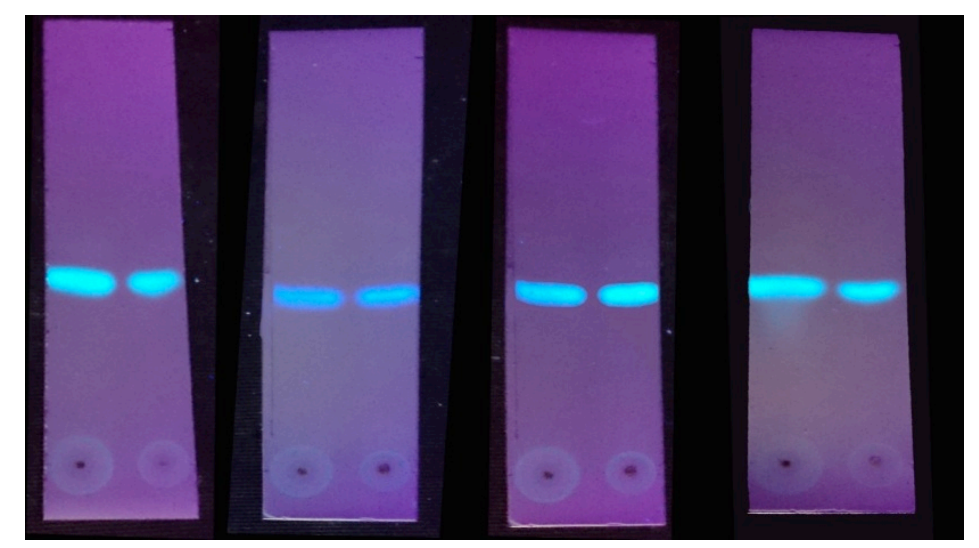
(A)
(B)
(C)
(D)

Gambar 2. Hasil uji KLT sebelum (kiri) dan sesudah (kanan) pengeringan ekstrak buah mengkudu dengan perbandingan (A) 2:1; (B) 1:1; (C) 1:2; dan (D) 1:3 dengan fase diam Silica gel $\mathrm{GF}_{254}$ ' fase gerak eter P-benzen P-asam asetat (5:5:1), dan penampak noda UV $365 \mathrm{~nm}$ 
ini melalui hibah Penelitian Kompetitif pada skim Green Technology dalam bidang Material Science \& Engineering.

\section{Daftar pustaka}

1. Manjula SN, Ali M, Kenganora M. Healths benefits of Morinda citrifolia (Noni): A Review. Pharmacognosy Journal. 2016;8(4):321-34.

2. Djauhariya E, Rahardjo M, Ma'mun. Karakterisasi Morfologi dan Mutu Buah Mengkudu. Buletin Plasma Nutfah. 2006;12(1):1-8.

3. Wijayakusuma HM, Dalimarta HS, Wirian AS, Yaputra T, Wibowo B. Tanaman Berkhasiat Obat di Indonesia. Jakarta: Pustaka Kartini; 1992.

4. Krishnaiah D, Hiaw KB, Sarbatly R, Anisuzzaman SM, Nithyanandam R. Spray Drying of Morinda citrifolia L, and Beta vulgaris L, Fruit Extract and Its Synergistic Effect. International Journal of Chemical Engineering and Applications. 2012;3(6):380-4.

5. ECETOC. Synthetic Amorphous Silica, JACC No.5. Belgium: European Centre for Ecotoxicology and Toxicology of Chemicals. 2006.

6. Depkes RI. Parameter Standar Umum Ekstrak Tumbuhan obat, Direktorat Jendral Pengawas Obat dan Makanan-Direktorat Pengawasan Obat Tradisional, Jakarta; 2000.

7. Siregar CJP. Teknologi Farmasi Sediaan Tablet: Dasar-dasar Praktis. Jakarta: Penerbit Buku Kedokteran EGC; 2010.
8. Ansel HC. Pengantar Bentuk Sediaan Farmasi, Edisi IV, diterjemahkan oleh Ibrahim, F. Jakarta: Universitas Indonesia Press; 2005.

9. Sinoga CJP. Teknologi Farmasi Sediaan Solida Tablet Dasar-Dasar Praktis., Bogor: Gagas Media; 2008.

10. Hasyim N, Mirawati SS. Pengembangan formulasi tablet matriks gastroentertentive floating dari amoksisilin trihidrat. Majalah Farmasi dan Farmakologi, 2012;16(3):131-8.

11. Depkes RI. Farmakope Herbal Indonesia edisi I, Jakarta: Direktorat Jenderal Pengawasan Obat dan Makanan; 2008.

12. Wagner H, Bladt S. Plant Drug Analysis, second edition. Germany: Springer; 1996.

13. Agoes G. Teknologi Bahan Alam. Bandung: Penerbit ITB; 2009.

14. Hadisoewignyo L. Sediaan Solida. Yogyakarta: Pustaka Pelajar; 2013.

15. Lachman L, Herbert AL, Joseph LK. Teori dan Praktek Industri Farmasi Edisi III. Jakarta: Penerbit Universitas Indonesia; 2008

16. Cartensen JT. Pharmaceutic of Solid and Solid Dosage Forms. Lancaster-Basel: Technomic Publishing Company Inc;1977.

17. Voigt R. Teknologi Farmasi, Edisi Kelima. Yogyakarta: Gajah Mada University Press;1995.

18. Wang MY, West BJ, Jensen CJ, Nowicki D, Chen SU, Palu AK, Anderson G. Morinda citrifolia (Noni): A literature review and recent advances in Noni research. Acta Pharmacologica Sinica. 2002;23(12):1127-41. 